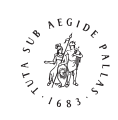

B R I L L

\title{
Political Life: Giorgio Agamben and the Idea of Authority
}

\author{
Steven DeCaroli \\ Goucher College
}

\begin{abstract}
This article explores the relation between biological life and political life, placing it in the context of the ancient Greek distinction between the life of the home (the oikos) and the realm of politics (the polis). In contrast with the oikos, the life of the polis was characterized by attempts to exclude from its sphere both the constraints of necessity that oblige human action to conform to the exigencies of survival as well as the violence that accompanies this pursuit. Although this exclusion has never been successful, the question of how to achieve it lies at the heart of the oldest philosophical reflections on politics and, in a more concealed fashion, remains central to our political concerns today. Invoking the work of Giorgio Agamben, this article explores the earliest discussions concerning the question "what is political life?" to show why so much depends upon how we answer this question.
\end{abstract}

Keywords

Agamben, authority, political life, violence, state of emergency, Arendt

Virtue can be no object of the state.... Were all its members virtuous it would lose its character of a compulsive power altogether. ${ }^{1}$ — Johann Gottlieb Fichte

\section{Survival}

There is a bond between necessity and violence to which the long history of political thought testifies. As living beings, fundamentally concerned with the preservation of life, humanity is confronted with needs and driven by necessity, and so, before the "good life" promised by politics is made possible, the resources necessary for sheer life must be secured. "No man can live well,"

1) Johann Gottlieb Fichte, The Characteristics of the Present Age, trans. William Smith (London: John Chapman, 1847), 175 . 
Aristotle tells us, "or indeed live at all, unless he is provided with necessities."2 It is for this reason that Aristotle dedicates the first book of the Politics to a discussion of the private domain of the household, the oikos, which in addition to being characterized by its role in procuring the pre-political necessities of daily living, serves as the backdrop against which the public character of the polis will be defined. In a similar fashion, the theory of the "state of nature," which enters political discourse at the beginning of the modern period, also serves as a backdrop to political life, making explicit what is only implied in Aristotle. Not only does the pre-political state of nature replace the prepolitical oikos as the site of permanent biological demands, but Hobbes' notion of the "right of nature" ( jus naturale) also confirms that each individual retains an extra-juridical authority to defend life through violent means. ${ }^{3}$ Whatever the case may be, and despite various formulations, there remains an indisputable truth in the fact that biological life burdens every living being with the most primal and profound sort of necessity, which is to say, survival. It is important to bear in mind, however, that survival does not simply mean to live; rather, to survive means to outlive (from the Latin supervivere, literally to "over-live"), and it is apparent that in surviving, what one outlives, what one outlasts, moment by moment, is necessity itself.

One of the clearest expressions of the relation between necessity and violence comes to us from Hannah Arendt. Writing in The Human Condition, she observes, "What all Greek philosophers, no matter how opposed to the polis life, took for granted is that freedom is exclusively located in the political realm, that necessity is primarily a prepolitical phenomenon, characteristic of the private household organization, and that force and violence are justified in this sphere because they are the only means to master necessity." ${ }^{4}$ The distinguishing trait of the household is that it is ruled by necessity, not law, and those who gather together under its jurisdiction do so not according to choice but in compliance with the demands of biological survival. As long as one remains exclusively within the domain of the oikos, however, mastering the necessities of life will involve exposure to the risk of violence, not simply because "no manexerted violence, except the violence used in torture, can match the natural

2) Aristotle, The Politics 1253b24-26, trans. Stephen Everson (Cambridge: Cambridge University Press, 1990); translation slightly modified.

3) Hobbes defines the right of nature as, "the Liberty each man hath, to use his own power, as he will himself, for the preservation of his own Nature; that is to say, of his own Life" (Leviathan, ed. Edwin Curley [Indianapolis: Hackett Publishing Company, 1994], chap. 14).

4) Hannah Arendt, The Human Condition (Chicago: University of Chicago Press, 1958), 31. 
force with which necessity itself compels," ${ }^{5}$ but because every necessity conceals the potential for an emergency.

In contrast with the oikos, the life of the polis was characterized by attempts to exclude from its sphere both the constraints of necessity that oblige human action to conform to the exigencies of survival as well as the violence that accompanies this pursuit. By marking out a space in which necessity was no longer permitted to rule-that is, by erecting a juridical order as a buffer against the natural order - the political community of the polis sought to evade necessity. ${ }^{6}$ Politics in classical Greece was, therefore, founded in opposition to the demands of living, which is why, as Arendt goes on to observe, in ancient times politics was never undertaken for the sake of life. According to Aristotle's account, humans initially form communities simply to survive, but this form of association, far from being exclusively human, is characteristic of many forms of animal life. Thus, when Aristotle defined the nature of human life as zōon politikon, it was not the case that he was unaware of or unconcerned with the fact that human beings require mutual companionship in order to satisfy the biological necessities of living, but rather, he did not consider the necessity of this condition to be exclusively human. It is only after the requirements of life have been secured that a fraction of humanity can set about forming a properly political community, the free and unencumbered domain of the polis, from which the labor necessary to maintain life is categorically excluded. In classical antiquity, whereas life in general was characterized by necessity, the highest expression of human life was distinguished by a uniquely political manner of living, which was, strictly speaking, unnecessary.

It would be easy to assume at this point that we have already reached a fundamental truth, that the classical separation of the political from the biological exposes an essential opposition between politics and life and that, by extension, there is an equally clear line separating freedom from necessity, and goodwill from violence. But this would be a mistaken assumption because the absolute separation of the polis from the oikos has, in fact, never held fast, first, because the polis cannot exist without the necessary work of the oikos and, second, because, as we will see, the logic of political life generates formidable

5) Arendt, The Human Condition, 129. "It is for this reason that the Greeks derived their word for torture from necessity, calling it anagkai, and not from bia, used for violence as exerted by man over man."

6) As is well known, Agamben draws a critical distinction between two terms used in classical Greek to refer to what we mean by the single term "life": zoe (natural or biological life; the sheer fact of being alive) and bios (political life; the way of life proper to an individual or group), which correspond with the oikos and the polis respectively. 
necessities of its own. To put it simply, the classical imperative to constitute political life as a buffer against the necessity and violence of biological life ultimately fails, but this failure is, we might say, incomplete. For unlike those failures that bring projects to their end, the failure of Western politics to escape necessity remains nevertheless sustainable, and as we will see, it is the idea of authority that does the work of preserving the political state beyond the limits of its failure.

The demands of biological life have always, from time to time, erupted within the polis and when raw necessity confronts the juridical order, when the need for survival impinges upon the aims of politics, the force of law begins to deteriorate. It is well known that, for Aristotle, membership in the polis was possible only through the strict exclusion of those-slaves, women, etc.whose lives remained tethered to the labor required for survival, and so it is not surprising that it is from out of their ranks that the juridical order of the polis first encounters its antithesis, that is to say, the poor - the name given to the appearance of biological necessity within the borders of the state. It is not by accident that when, in book two of the Politics, Aristotle writes that "poverty is the parent of revolution and crime" (1265b13), he explicitly associates the appearance of poverty with both illegality and insurrection, for beyond a certain threshold poverty no longer leads to crime (e.g., theft or larceny) but to the demise of the very legal order that makes crime itself intelligible. ${ }^{7}$ Poverty, then, is antithetical to the political because it introduces necessity into a domain of life which has historically been defined by its absence-a truth born out repeatedly in classical literature. In Alcaeus, for instance, we read that Penia, the Greek goddess of poverty, is ungovernable. "Penia (Poverty) is a grievous thing, an ungovernable evil, who with her sister Amakhania (Helplessness) lays low a great people." 8 While in the Histories, Herodotus recounts the story of the Greek general Themistocles who commands the inhabitants of the small island of Andros to surrender their money. Having no money to give, the islanders

\footnotetext{
7) Plato, of course, was also well aware of this. In book five of the Laws, he speaks of the imbalance that excessive poverty, as well as excessive wealth, brings to a community. "In a state which is desirous of being saved from the greatest of all plagues - not faction, but rather distractionhere should exist among the citizens neither extreme poverty, nor, again, excess of wealth, for both are productive of both these evils" $(744 \mathrm{~d} 2-5)$. He describes poverty not in terms of material needs but in terms of subjective desires. Poverty, he writes, is "the increase of a man's desires and not the diminution of his property" (736e2-4) (Plato, Laws, trans. Benjamin Jowett [Amherst: Prometheus Books, 200o]).

8) Alcaeus, "Fragment 364," in Greek Lyric: Sappho and Alcaeus, trans. David A. Campbell (Cambridge: Harvard University Press, 1982).
} 
offer instead a non-negotiable response, "Since we are in the hands of these gods [Penia and Amekhania], we will give no money; the power of Athens can never be stronger than our inability." ${ }^{\text {In }}$ both cases, impoverishment is presented as a type of necessity, which, being both ungovernable and undefeatable, commands an authority that lies beyond the reach of the juridical order.

In an analogous fashion, and with reference to more modern times, in the pages of On Revolution Arendt provides an equally instructive account of an encounter between poverty and the state, in this case framed by the ideals of the French Revolution.

$[\mathrm{P}]$ overty is abject because it puts men under the absolute dictate of their bodies, that is, under the absolute dictatorship of necessity as all men know from their most intimate experience and outside of all speculations. It was under the rule of this necessity that the multitude rushed to the assistance of the French Revolution, inspired it, drove it onward, and eventually sent it to its doom, for this was the multitude of the poor. When they appeared on the scene of politics, necessity appeared with them, and the result was that the new republic was still born; freedom has to be surrendered to necessity, to the urgency of the life process itself. ${ }^{10}$

When biological necessity surfaces within the borders of the state, it does so in the form of poverty, and there is simply no law that can be written that is severe enough to prevent its being broken in circumstances where what is necessary is either scarce or unavailable. Although the state maintains the coercive power necessary to defeat poverty through force or to sequester it through criminalization, in the long run poverty heralds the demise of the state because, in accordance with the Aristotelian model, in the face of necessity politics cannot survive.

But the appearance of poverty is not the only manner in which the separation of the biological from the political, the oikos from the polis, reveals its fragility, for the state is concerned with its own survival as well. The violence that political life sought to avoid by excluding necessity from its domain reappears in the form of necessities born within the political order itself - a purely political form of survival. While it is true that without food there can be no civil society, no public life, the survival of the polis is not measured in the same way one measures the survival of the oikos. The survival of the state is not entirely, nor even necessarily, aligned with the survival of the poor but is, rather,

\footnotetext{
9) Herodotus, The Persian Wars, Books VIII and IX, trans. A. D. Godley (Cambridge: Harvard University Press, 1920), 8.111.1.

10) Hannah Arendt, On Revolution (New York: Viking Press, 1977), 50.
} 
dependent upon preconditions that make the rule of law viable. Thus, when Carl Schmitt famously states that no rule is applicable to chaos, and that therefore "[f] or a legal order to make sense, a normal situation must exist,"11 he is referring to precisely the preconditions that are necessary for political survival. The law can only exist under pre-given conditions that permit the source of its authority to go unquestioned, and for Schmitt, the guarantor of these preconditions is of course the sovereign. The primary work of sovereignty is not to impose the law but to maintain a stable, coherent order within a community such that the logic of the legal system, once created, will be capable of giving commands that are regularly obeyed. The true role of sovereignty, upon which the entire survival of political life rests, is to make command possible by making obedience normal, and as we will see, it is in this sense that sovereignty is rooted not in potestas but in auctoritas, for the principal role of sovereignty is not to make the law but to give it force.

If the survival of political life depends upon a precondition of normal obedience, what Schmitt refers to as "a normal, everyday frame of life,"12 then whenever this preconditional "frame of life" is placed in jeopardy, the state, facing death, takes emergency action. When political life appears on the verge of collapse, when the ability to extend force to law is in jeopardy, the political order begins to mirror the biological order by calling upon extra-juridical legitimacy to preserve the life of the state through the use of violence. As we have seen, the legitimate exercise of this violence derives from the necessity of the situation, because, just as in the case of biological survival, necessity introduces the potential for emergency action. But the parallel between the biological order and the juridical order comes to an end here, because, whereas life enters a state of emergency whenever objective conditions give rise to the risk of death, the state enters a state of emergency strictly by way of a decision. It is for this reason that the theory of the political emergency, most notably in the writings of Carl Schmitt, places the decision at the center of its concern. The decision regarding whether or not conditions have risen to the level of an emergency not only distinguishes political necessity from biological necessity, political life from biological life, but also constitutes the politicization of survival itself.

But what happens when political life, which has historically been defined by the complete exclusion of necessity, enters a state of emergency that brings to light the presence of necessity within the political order itself? When political life confronts the manifestation of its own necessity, how are we to understand

11) Carl Schmitt, Political Theology: Four Chapters on the Concept of Sovereignty, trans. George Schwab (Cambridge: MIT Press, 1985), 13.

12) Schmitt, Political Theology, 13. 
the political, especially when a consequence of this necessity is the suspension of law and the emergence of extra-legal violence? If the introduction of the emergency into the polis happens because political existence is in fact a type of life, what type of life is this? And more specifically, who within the polis is invested with the capacity to decide whether or not this political life is or is not at risk of death? In what follows, and in continuation of the line of inquiry presented so far, I would like to explore these questions in light of Giorgio Agamben's political thought not only to provide answers but to understand why, following Agamben, life is not primarily a biological concept but a political fact.

\section{Division}

Every time one considers the nature of politics one finds alongside it the division of life. According to Aristotle, the only true concern politics has with natural life is in distinguishing itself from it, and this separation involves not only marking divisions between human life and the lives of other animals but also of establishing divisions within human existence itself. Everything hinges upon how life is divided, not upon how life is defined as such. Division is not, however, merely a question of sorting pre-existing types. Rather, division is the original act of politics in which what is divided comes into being as a consequence of division. Life, therefore, is defined in terms of politics, not the other way around, and this definition is never given absolutely but appears only as the relative relationship between groups that have been separated.

It is not surprising, then, that the state frequently directs its violence toward those who, through division, are excluded or disenfranchised from the proper domain of politics, for they are not the ones the state was designed to protect. Aristotle is quite clear on this point, for as we have seen, the entire first book of the Politics is devoted to establishing and then setting aside the inferior status of women and the existence of natural slaves. Likewise, Aristotle is unambiguous in stating that only a slim fraction of the community can be included in the polis, and for the rest life in the oikos is by definition their natural condition. This is why so much of the first book of the Politics is devoted to spelling out in no uncertain terms that there are human beings whose lives form a zone external to the polis. In characterizing these lives in terms of an inferior ontology, the work of legitimating their exclusion is taken care of in advance, and so, it is evident that these excluded forms of life, which are said to be excluded because of the types of being they are, are in fact fabrications of the logic of the political order itself. This is why, for Agamben, life is a thoroughly political concept 
having nothing at all to do with biology. The creation of political life, which for Aristotle is the uniquely human form of life, has always had the shadow effect of creating a distinct notion of biological life in contrast to which the political order is defined and made viable. The state was never designed to protect those whose lives remain bound to the oikos, and while societies have over time, and particularly during the last two hundred years, extended the state's protection to more and more forms of life, the structural problem of division that characterizes the Western political order remains in place.

Not only is the political order that which excludes the necessities of life from the sphere of human activity, it also divides life from within, putting life in relation with itself according to a necessity that arises from within political existence. But as Agamben sees it, it is the act of separation — an original political act - that produces the idea of a natural life in the first place, and it is on this point that Agamben parts ways with both Aristotle and Arendt, because for him $z o \bar{e}$, or natural life, is not a pre-existing natural substrate but the product of a historical separation. From this perspective, natural life $(z o \bar{e})$ is politicized by its being excluded, and thus, as Agamben observes, it "has the peculiar privilege of being that whose exclusion founds the city of men [the polis]."13 When Agamben writes, early in the pages of Homo Sacer, that his present inquiry concerns the point of intersection between political life and bio-political life, it is the production of this politicized life that he has in mind. "It can even be said," he writes, "that the production of a biopolitical body is the original activity of sovereign power." 14

Those who are excluded by the political order, those who reside exclusively in the oikos rather than in the polis, therefore suffer a double threat. On the one hand, there are of course the requirements of nature-"necessity's grim law"15_ which all must satisfy or perish. But to be excluded from the political order is not the same as simply existing in a pre-political environment. Rather, to be excluded from the political is, as Agamben proposes with such conviction, to be politicized through one's exclusion. The life that exists in this condition is what Agamben famously calls "bare life," which must not be equated with simple biological life, because the survival of bare life is conditioned not only by the elemental needs of biological existence but by the juridical needs

13) Giorgio Agamben, Homo Sacer, trans. Daniel Heller-Roazen (Stanford: Stanford University Press, 1998), 7 .

14) Agamben, Homo Sacer, 6.

15) Euripides, The Plays of Euripides, trans. Edward P. Coleridge, vol. 1 (London: George Bell and Sons, 1891), 243. 
of political existence as well. In other words, the daily struggles for survival for those who remain outside the polis entail not only periodic encounters with the caprice of nature's fury but continual encounters with the violence of the state stemming from the fact that the state, and the political life it sustains, ruthlessly pursues a survival of its own. Under normal conditions, the division of life serves to meet the demands of this political survival, but when the state can no longer keep necessity at arm's length, when the normal condition is lost, sooner or later an emergency will be declared.

Every effort to define politics has required defining the divisions of life such that certain forms of life can be attributed not only the legitimacy to participate within the political domain but, in a more exceptional fashion, are granted the legitimacy to rule. In either instance, what appears to be the precondition for politics, i.e., the discovery of differences, is in fact the principle work and consequence of politics itself. In the twenty-four centuries that have passed since Aristotle formulated his theory of politics, solutions to the problem of the rift between biological life and political life have been attempted but have succeed only provisionally or not at all. "Western politics," Agamben laments, "has not succeeded in constructing the link between zoe and bios... that would have healed the fracture."16 Instead, biological life remains included in politics in the impoverished form of an exception. Until a new politics appears, Agamben claims, setting the agenda for his expansive and ongoing political project, one that is no longer founded on the exclusion of the oikos, on the exclusion of the necessities that drive biological existence, every theory of the state will reinforce this divide, bringing with it the exceptional, extra-juridical violence of the political emergency.

\section{Status Necessitatis}

Chapter three of the State of Exception is devoted to an analysis of a peculiar institution of Roman law, the statute of iustitium, which, Agamben claims, once it is properly understood, will assist in "untangling the aporias that the modern theory of the state of exception cannot resolve." ${ }^{17} \mathrm{He}$ begins, as is so often the case, with an analysis of the legal and etymological history of the term. We learn that under the most dire conditions, in situations where the very existence of the Republic was endangered, the Senate would issue a

\footnotetext{
16) Agamben, Homo Sacer, 11.

17) Giorgio Agamben, State of Exception, trans. Kevin Attell (Chicago: University of Chicago Press, 2005), 41.
} 
so-called "final decree" (senatus consultum ultimum) whereby it called upon the consuls and citizenry alike to use whatever means necessary to defend the state once it had become clear that the law no longer could. At the center of this extreme measure was, in addition to a declaration of tumultus (a formal acknowledgment of insurrection or war), also the proclamation of iustitium, which entailed a complete "suspension of the law"; literally a juridical standstill linked etymologically to the still-point of the sun at the solstice. The condition resulting from this decree was not merely the cessation of the protocols of justice but the putting out of operation of the law in its entirety-the creation of a juridical vacuum.

Having described in some detail the scholarly literature concerning the concept, Agamben introduces a theme that will occupy him throughout the remainder of the book: the lawless, anomic space that coincides with the city after law has been suspended, and the subsequent collapse of any distinction between public order and private life, between the polis and the oikos. Here is how Agamben frames it:

The iustitium seems to call into question the very consistency of the public space; yet, conversely, the consistency of the private space is also immediately neutralized to the same degree. In truth, this paradoxical coincidence of private and public, of ius civile and imperium, and, in the extreme case, of juridical and nonjuridical, betrays the difficulty or impossibility of thinking the essential problem: that of the nature of acts committed during iustitium. ${ }^{18}$

What, in other words, is the legal status of acts committed at a time during which the law is at a standstill, especially given the further consideration that this standstill is initiated in the service of the juridical order's ultimate protection? Agamben's answer is straightforward, "In truth," he writes, "the entire question is poorly put,... [for] it is entirely clear that the magistrate or private citizen who acts during the iustitium neither executes nor transgresses the law, and even less does he create law."19 As long as the anomic situation is in effect, the legal quality of all actions remain absolutely undecidable, "and the definition of their nature - whether executive or transgressive, and, in the extreme case, whether human, bestial, or divine - will lie beyond the sphere of law."20 But left unanswered is a further question, which, while entailed by the first, cannot be answered in the same manner: How does the command, given here

\footnotetext{
18) Agamben, State of Exception, 49.

19) Ibid., 50.

20) Ibid.
} 
as a sweeping injunction to preserve the state (res publica) by means of any action whatsoever, survive and remain in effect in the absence of a legal framework? Not only is it entirely unclear how the command retains its force, but it is equally uncertain as to the meaning of obedience in this situation. To whom is one's obedience given? This question is not directly answered by Agamben, at least not within the pages of the chapter in question, but he clearly recognizes its centrality, pointing to commentary by both Mommsen and Nissen regarding the preservation of an "unlimited command" and an equally "unlimited obedience" that survive the suspension of law and persist within the anomic space that remains. This space, which is devoid of law, is presented as essential to the survival of the juridical order, so much so that at every turn we find the law reasserting its relation to the anomic, suggesting a decisive connection between them. By the end of the chapter Agamben hints at the character of this connection and in doing so points in the direction of an answer to the question concerning command, namely, that the operability of command within the juridical void is bound to the concept of authority, a power that persists despite the law, or in Agamben's words, a "force of law that is separate from the law," or more succinctly, a "floating imperium." ${ }^{11}$

The term favored by Agamben to indicate the suspension of normal juridical order during extreme times, such as under a proclamation of iustitium, is "state of exception," but as he notes in the opening pages of his book of the same name, while "the present study will use the syntagma state of exception as the technical term for the consistent set of legal phenomena that it seeks to define,"22 other synonymous terms are in common use. In French and English legal theory, for instance, terminology emphasizing a condition of emergency prevails, e.g., emergency decree, emergency power, or state of emergency. While Agamben's decision to use "state of exception" as his preferred term has semantic advantages, not the least of which is the fact that the term is commonly employed to translate Schmitt's usage of Ausnahmezustand, ${ }^{23}$ it is important to remember that each time Agamben speaks of the exception, his reference gestures to an emergency. Whereas the idea of an exception can come across as somewhat vague and abstract, the notion of an emergency allows us to see clearly not only the immediate, concrete relationship that the

\footnotetext{
21) Agamben, State of Exception, 51.

22) Ibid., 4.

23) This is the case even though the most literal translation of Ausnahmezustand is, in fact, "state of emergency."
} 
juridical crisis has with life but also serves to foreground the link that joins necessity to violence.

That Agamben is well aware of the connection between the exception and the emergency is clear from the first chapter of the State of Exception where he tells us that there is a long standing opinion that the state of exception is founded on the idea of necessity. After referencing a well known Latin adage, necessitas legem non habet ("necessity has no law"), he goes on to state that "[t]he theory of the state of exception is wholly reduced to the theory of the status necessitatis, so that a judgment concerning the existence of the latter resolves the question of the legitimacy of the former."24 Everything depends here upon the sudden emergence of necessity within the political sphere. All of the extreme, extra-juridical measures taken by the state once the political order has entered a state of exception are justified entirely on the grounds that they are necessary responses to necessity conditions. But, as we have seen, what it means for necessity to appear within the state, that is to say, what it means for necessity to become politically real, has nothing to do with an objective encounter. Instead, political necessity is the direct result of a discrete political judgment (or decision) regarding whether or not an emergency has occurred. And since the demands of necessity supersede the law, once the decision regarding the survival of the state has been made, anything becomes possibleeven though the precise legal status of such action remains ambiguous.

Although Agamben notes the presence of political necessity, status necessitates, in the pre-modern period-he draws our attention, for instance, to Gratian's Decretum ("If something is done out of necessity, it is done licitly, since what is not licit in law necessity makes licit."), as well as to Thomas Aquinas ("If there is, however, a sudden danger, regarding which there is no time for recourse to a higher authority, the very necessity carries a dispensation with it, for necessity is not subject to the law.") - he claims that it is not until modern times that we find necessity fully included within the juridical order, appearing both in defense of established systems and as a revolutionary source of new norms. "[I]n the forms of both the state of exception and revolution," he writes, "the status necessitatis appears as an ambiguous and uncertain zone in which de facto proceedings, which are in themselves extra- or antijuridical, pass over into law, and juridical norms blur with mere fact." ${ }^{25}$ Under conditions of necessity, when the oikos surfaces within the polis, life and law begin to blur, thereby calling into question the decisiveness of their presumed separation. "In any

24) Agamben, State of Exception, 24.

25) Agamben, State of Exception, 29. 
case," he writes in the opening pages of Homo Sacer, "the entry of zoe into the sphere of the polis - the politicization of bare life as such-constitutes the decisive event of modernity and signals a radical transformation of the political-philosophical categories of classical thought." 26

Situated at the threshold of the modern period, the writings of Machiavelli best embody the modern form of political necessity. Although Agamben mentions him only briefly, Machiavelli is the first to make explicit both the extralegal conditions necessary for the possibility of law and, consequently, the fundamental role of the prince in keeping these conditions intact. Following the remarks of Giovanni Giorgini, The Prince must be seen as a text devoted to managing the problems that arise when it becomes necessary either to set up the conditions for the possibility of politics or to save the political community from destruction. The Prince, in other words, should be read "as a variation on the theme of the status necessitatis, namely on the extreme and exceptional condition in the life of a political community." 27 Likewise, in the Discourses, Machiavelli states plainly that "when the safety of one's country depends wholly on the decision to be taken, no attention should be paid either to justice or injustice, to kindness or cruelty, or to its being praiseworthy or ignominious. On the contrary, every consideration being set aside, that alternative should be wholeheartedly adopted which will save the life and preserve the freedom of one's country." ${ }^{28}$ Stating the case with particular clarity, Giorgini concludes that, for Machiavelli, "ruling and law-giving according to reason and justice presuppose the existence of the State, of a political structure capable of exercising its jurisdiction on a people and it is in the status necessitatis that the truth emerges that, before we can have politics and the rule of law, we need the extra-legal means of the prince in order to create or preserve the State." 29

But for our purposes, by far the most important aspect of Agamben's treatment of status necessitatis is his insistence, following the work of Giorgio Balladore-Pallieri, that political necessity is unique because, even though "writers continue more or less unconsciously to think of [it] as an objective situation,"30 its existence within the state is actually determined on a subjective basis. "Far from occurring as an objective given," Agamben writes, "necessity clearly

\footnotetext{
26) Agamben, Homo Sacer, 4.

27) Giovanni Giorgini, "The Place of the Tyrant in Machiavelli's Political Thought and the Literary Genre of the Prince," paper presented at the Italian Academy for Advanced Studies, Columbia University (February 18, 2004), 7.

28) Niccolo Machiavelli, The Discourses, ed. Bernard Crick (New York: Penguin, 1970), 515.

29) Giorgini, "The Place of the Tyrant in Machiavelli's Political Thought," 7.

30) Agamben, State of Exception, 29.
} 
entails a subjective judgment, and that obviously the only circumstances that are necessary and objective are those that are declared to be so." ${ }^{31}$ This point cannot be over emphasized. As we have already seen, whereas biological necessity confronts us as a brute, objective fact, bound as it is to starvation, disease, and death, political necessity appears only when a decision has been made regarding the stability of the legal order. As Balladore-Pallieri observes, "The concept of necessity is an entirely subjective one, relative to the aim that one wants to achieve." ${ }^{32}$ And although it is often argued that purely objective conditions dictate the issuance of an emergency command, because otherwise the existing juridical order would perish, this claim remains blind to a basic fact that Balladore-Pallieri brings to our attention: first and foremost, "there must be agreement on the point that the existing order must be preserved." 33 That the political system has a value worth preserving is not a given, and consequently, within the scope of the political order, the value of survival itself turns out to be the consequence of a political decision. In this way, the decision regarding the political emergency is directly connected to the conception of political life, because in deciding whether or not the survival of political life is at risk, or is even worth preserving, the decision implicitly determines the scope of what constitutes political life itself.

\section{Continuity}

But what does it mean for a political life to survive? The question can be approached in several ways, but certainly political survival has nothing to do with the meaning of survival in the common biological sense. The state, for instance, has always reserved the means to terminate the political life of its citizens without ending their biological life. The long history of banishment and exile, which accompanies the emergence of the political order from its inception, dating back to at least the Hammurabic Code, testifies to this point. And so, for instance, we read in Beccaria that, in the case of exile, "the citizen dies; the man only remains, and, with respect to a political body, the death of the citizen should have the same consequences with the death of the man."34

\footnotetext{
31) Ibid., 30.

32) Giorgio Balladore-Pallieri, Diritto costituzionale (Milan: Giuffrè, 1970), 168, quoted in Agamben, State of Exception, 3 .

33) Balladore-Pallieri, Diritto costituzionale, quoted in Agamben, State of Exception, 30.

34) Cesare Beccaria, On Crimes and Punishments, ed. Adolph Caso (Boston: International Pocket Library, 1992), 58-59. For a more detailed treatment of banishment and civil death see my
} 
But the political life (or death) of the citizen is not the same as the political life of the sovereign because, as Agamben explains, "unlike the life of the common citizens, the 'august' life can no longer be defined through the opposition of public and private." 35 The separation of the private domain of the oikos from the public domain of the polis, which constituted for Aristotle the decisive feature of political life, does not apply to the sovereign whose relationship to life and law remains ambiguous. Dio Cassius tells us, for instance, that Augustus "made all of his house public... so as to live at once in public and in private."36 And the unique relation that the sovereign has to private life, to the domus, is directly related to the unique role sovereign power plays in political life, namely, the exercise of authority (auctoritas), and is the reason his private, biological death had such dire implications for the general survival of public, political life as such.

In the final chapter of State of Exception, Giorgio Agamben defines the concept of auctoritas, used in Roman law in contrast to potestas (and imperium). In political contexts, while potestas referred to the power or ability to achieve certain ends, auctoritas referred to a claim of legitimacy, the right to exercise power. One who possessed auctoritas held the capacity to confirm, or to give, a thing its completeness. The auctor was he under whose authority a legal act was accomplished. Theodor Mommsen describes the force of auctoritas as "more than advice and less than command, an advice which one may not safely ignore,"37 and Arendt, drawing attention to the non-juridical quality of the person in whom authority resides, tells us that "[ $\mathrm{t}]$ he most conspicuous characteristic of those in authority is that they do not have power." ${ }^{38}$ Authority, then, is a capacity that resides both outside of the legal order and within a specific individual (rather than as the result of holding an office). Quoting Richard Heinze on this matter, Agamben explains: "Every magistracy is a preestablished form, which the individual enters into and which constitutes the source of his power [i.e., the power invested in a position]; auctoritas, on the other hand, springs from the person, as something that is constituted through him,

\footnotetext{
essay, "Boundary Stones: Giorgio Agamben and the Field of Sovereignty," in Giorgio Agamben: Sovereignty and Life, ed. Matthew Calarco and Steven DeCaroli (Stanford: Stanford University Press, 2007), 43-69.

35) Agamben, State of Exception, 83 .

36) Dio Cassius, Roman History, 55.12.5, quoted in Agamben, State of Exception, 82.

37) Theodor Mommsen, Römisches Staatsrecht, p. 1034, quoted in Hannah Arendt, "What is Authority?," in Between Past and Future (New York: Penguin Books, 1977), 123.

38) Arendt, "What is Authority?," 122.
} 
lives only in him, and disappears with him."39 The problem of continuity, which posed such a problem for early monarchs and which frames the key challenge of political existence, arises from this unique overlap of public and private life that characterizes sovereignty.

Because the prince personifies authority through his actual body, and because authority must remain in effect if the juridical order is to remain legitimate, the entire history of Western political power has been consumed by the problem of continuity and by the development of strategies for ensuring it. ${ }^{40}$ For the political order to remain viable, authority must remain continuous, and so, with regard to the political life of the sovereign, survival cannot merely correspond to the biological lifespan of any particular emperor or prince because biological life is simply too fleeting. The death of the king must be managed by rituals of continuity so that the authority vested in the king's body outlives, that is to say, survives, the end of his biological life. If biological death is the most certain of all biological necessities, and if the political domain is

39) Richard Heinze, "Auctoritas," Hermes 60 (1925): 356. Quoted in Agamben, State of Exception, 82.

40) In The Human Condition, Arendt writes "The chief characteristic of this specifically human life, whose appearance and disappearance constitute worldly events, is that it is itself always full of events which ultimately can be told as a story... it is of this life, bios as distinguished from $z \bar{o} \bar{e}$, that Aristotle said that it 'somehow is a kind of praxis'” (97). Although not apparent at first, I believe that Arendt's observations here bear directly on the question of political survival, because unlike biological life that unfolds as part of the cyclical processes of nature, political life is fundamentally linear. Indeed, as Arendt goes on to say, it is only within the scope of human life, that is, a life capable of unfolding as a narrative, that "nature's cyclical movement manifests itself as growth and decay." Birth and death, she writes, "are not natural occurrences, properly speaking; they have no place in the unceasing, indefatigable cycle in which the whole household of nature swings perpetually." Only when beings are encompassed by the human world-by placing "this tree or this dog" into our world—can the cyclical permanence of natural life be meaningfully characterized by growth and decay. Properly human life according to Aristotle, the political bios of humanity, is unique because each of its characteristic modes of appearance can take the form of a narrative. "For action and speech, which, as we saw before, belonged close together in the Greek understanding of politics, are indeed the two activities whose end result will always be a story with enough coherence to be told" (97). Thus, judgment regarding the viability of the political order is not only communicated through, but is measured by, the ongoing coherence and continuity of this story. When the narrative begins to fray and the storyline fades, this is when a decision must be made regarding the viability of the form of life, the bios, that constitutes the political order. Indeed, the political emergency is possible — that is to say, becomes legible — only because life of the polis is intelligible as a fundamentally historical narrative. Only by ordering life in terms of a linear chronology does it become conceivable to speak in term of origins and foundations, but equally, the linear temporality of human life makes continuity fragile and in need of constant management and vigilance. 
distinguished by its distance from such necessity, then the capacity to extend (political) life by surviving (biological) death is undoubtedly the greatest triumph of the political sphere.

The critical importance of this political suspension of death can be seen most clearly in the medieval practices of kingship made famous in the work of Ernst Kantorowicz. As is well known, his writings investigate the two bodies of the king: the political body and the natural body. The biological death of the king, in whose hands authority resides, though inevitable, must not equate to the death of authority. It is only because "the sovereign expresses an auctoritas in his very person" that it becomes necessary to go to extreme lengths to "ensure the continuity of dignitas (which is simply a synonym for auctoritas)."41 Authority, which constitutes the life of the state, must survive the sovereign's natural death, and it can do so only according to a system in which the king has, in effect, two bodies, indeed, two lives, one of which is bound to the corporeal reality of flesh and another to political existence (often ritually represented by a wax effigy) that remains entirely free from the necessities of living, including death itself. "Undoubtedly," Kantorowicz writes, framing the issue with perfect clarity, "the concept of the 'king's two bodies' camouflaged a problem of continuity." 42 Thus, whenever we encounter the problem of authority, we confront the problem of continuity, which is, of course, also the problem of survival.

By way of example, Agamben recounts a description of Augustus' death in the year 14 CE. Writing as if at the foot of the royal deathbed, Agamben tells us of the old emperor's repeated inquiry as to whether a tumult had yet begun to occur on the streets - a period of lawlessness brought on by the pending demise of the sovereign as the source of juridical legitimacy. Tumult coincides with the death of the sovereign, which is "likened to civic catastrophes," 43 because the survival of authority is at risk. With the death of the emperor, necessity is introduced into the heart of the city. The life of the sovereign, situated both inside and outside the legal order, collapses the distinction between private and public, oikos and polis, and thus his biological death threatens political death as well—not simply his personal political death, but the death of the juridical order in its totality. Anomie, then, is not merely something that is produced by the sovereign's absence but is a condition that allies itself with

\footnotetext{
41) Agamben, State of Exception, 83 .

42) Ernst Kantorowicz, The King's Two Bodies (Princeton: Princeton University Press, 1985), 273.

43) Augusto Fraschetti, Roma e il principe (Rome-Bari: Laterza, 1990), 57, quoted in Agamben, State of Exception, 68.
} 
sovereignty from the beginning. "It is," Agamben writes, "as if the sovereign, who had absorbed into his 'august' person all exceptional powers ... and who had, so to speak, become a living iustitium, showed his intimate anomic character at the moment of his death and saw tumult and anomie set free outside of him in the city." 44

Having shown the intimate relation of the sovereign to lawlessness, or to the juridical exception, Agamben next turns his attention to the status of the sovereign as "living law" (nomos empsukhos), which signals a foundational moment in the development of the modern concept of sovereignty. "That the sovereign is a living law," he writes, "can only mean that he is not bound by it," 45 and thus, within the figure of the sovereign, life and law coincide, setting in place an indistinction between nomos and anomie, between law and that which is unbound by law. To illustrate this, Agamben refers us to a passage in Diotogenes, which Kantorowicz tells us was often quoted by medieval absolutists, that reads: "because the king has irresponsible power and is himself a living law, he is like a god among men." 46 Identified with the law, the sovereign is posited as the ontological foundation of the juridical order-the figural embodiment of a political first principle and, consequently, the precondition for the survival of the political order.

Thus, far from being merely a legal category, sovereignty is primarily an ontological category that, by being mistaken for a legal category, remains misunderstood. The emperor is sovereign not by law but under a set of informal social conditions that attribute to the emperor's life an ontological privilege. And so, upon the emperor's death the social order that comprises the norm precisely through its social acceptance of the unique ontological status of the sovereign as well as the status of "political life" he represents is revealed to be none other than the regularization of authority, once it has been embodied by the habits and attitudes of a people who are, and always have been, merely biological beings. The powers and privileges that are constitutive of the sovereign are made to be seen as entirely a consequence of his being as such, and the fact that such powers exist only for as long as they are acknowledged, recognized, or otherwise accepted by the people is either suppressed or controlled. The anarchy that threatens to spread throughout the city upon the sovereign's

\footnotetext{
44) Agamben, State of Exception, 68.

45) Ibid., 69 .

46) Louis Delatte, Les traités de la royauté d'Ecphante, Diotgène et Sthénidas (Paris: Droz, 1942), 39, quoted in Agamben, State of Exception, 69.
} 
death, Agamben writes, "must be ritualized," 47 because it is precisely this ritual practice that obscures from view the necessity that resides at the heart of the polis and political life, namely, the necessity of maintaining the fiction of authorial power.

In Agamben's analysis, then, it is auctoritas that has the power to suspend potestas, to announce the state of exception, the state of emergency, and so it is in auctoritas that the force of suspended law is isolated-an authority without law that holds sway in the absence of constituted power, making clear that it is authority, not law or potestas, which is required for the survival of political life. "Auctoritas and potestas are clearly distinct," Agamben writes, "and yet together they form a binary system." 48 But under extreme conditions, where an emergency has been announced, "auctoritas seems to act as a force that suspends potestas where it took place and reactivates it where it was no longer in force. It is a power that suspends or reactivates law, but is not formally in force as law." 49 Authority is "what remains of law if law is wholly suspended," and in this sense authority is "not law but life," a "law that blurs at every point with life."50 Being a living law, the sovereign, the auctor, makes the political emergency possible by making political necessity intelligible. Therefore, what we encounter in auctoritas is a manner of being rather than a manner of doing, and all questions concerning authority are, at their base, ontological in nature. In this respect, Agamben's formulation foregrounds the distinction between "the biopolitical tradition of auctoritas" and "the legal tradition of potestas,"51 and above all it is the affective influence of auctoritas that establishes it as the biopolitical anchor for constituted power - a quality he compares to the role charisma plays in the writings of Max Weber. "The juridical system of the West," Agamben continues, "appears as a double structure, formed by two heterogeneous yet coordinated elements: one that is normative and juridical in the strict sense [potestas], and one that is anomic and metajuridical [auctoritas]"52 — a distinction that "is founded on the essential fiction according to which anomie (in the form of auctoritas ...) is still related to the juridical order." 53

\footnotetext{
47) Agamben, State of Exception, 70.

48) Ibid., 78.

49) Ibid., 79 .

50) Ibid., 80.

51) Ibid., 84 .

52) Ibid., $85^{-86 .}$

53) Ibid., 86.
} 
So in the final analysis, political authority is a dependent power not only, as we discussed above, because political life depends upon the material necessities provided by the private domain of the household, the oikos, but because it also depends on the cognitive necessities, i.e., the belief and obedience, provided by the population. The status of political authority, and the capacities that derive from that status, are functional only insofar as they depend on the collective acceptance, intentional or otherwise, of the people over which power holds sway. Consequently, the acquisition of status and its subsequent preservation within the body politic is the primary interest of all sovereign power, and the emperor can never take this system of status for granted. It must be continually maintained.

\section{Living Law}

In book three of the Politics, Aristotle speaks of a curious political difficulty, namely, how the polis should deal with threats to its survival that are legal. While considering the problem, Aristotle introduces a figure whose mere presence within the polis poses a threat to political life, yet he describes this person with the same words Diotogenes uses to describe the king: a living law, a god among men. ${ }^{54}$ Although described in identical terms, Aristotle's figure functions in precisely the opposite manner of the sovereign-not as a life that preserves the law even in its absence, but as a life whose presence threatens to undo the law. The predicament imposed upon the state by this so-called "god among men" raises two preliminary questions: First, with respect to what constraints on sovereign political power is a legal act also a dangerous act? And, second, what forms of legality are so inassimilable to political order, and so threatening to political life, that sovereignty cannot contain them through criminalization, but must instead force these individuals into exile by withdrawing its jurisdiction from them? Here is how Aristotle frames the matter:

If, however, there be some one person, or more than one, ... whose virtue is so pre-eminent that the virtues or the political capacity of all the rest admit of no comparison with his or theirs, he or they can be no longer regarded as part of a state; for justice will not be done to

\footnotetext{
54) I have written about this subject previously, in an essay concerned with banishment. While the present discussion covers similar ground, it extends the earlier work by examining how the figure of a "god among men" relates specifically to the subject of "political life." See my essay, "Boundary Stones: Giorgio Agamben and the Field of Sovereignty," in Giorgio Agamben: Sovereignty and Life, 43-69.
} 
the superior... Such a one may truly be deemed a God among men. Hence we see that legislation is necessarily concerned only with those who are equal in birth and in capacity; and that for men of pre-eminent virtue there is no law-they are themselves a law. Any would be ridiculous who attempted to make laws for them.... And for this reason democratic states have instituted ostracism; equality is above all things their aim, and therefore they ostracized and banished from the city for a time those who seemed to predominate too much through their wealth, or the number of their friends, or through any other political influence. ${ }^{55}$

From the earliest of times, the principle of mediocrity has presided over the historic development of democratic governance. This was certainly the case in Athens, where the Delphic maxim "nothing in excess" guided Periclean politics and where ostracism helped ensure mediocrity within the state. Likewise, as Aristotle's words make clear, the exercise of justice requires the establishment of a situation in which a comparison between equals is possible. Where this comparison is not possible, justice is not possible. And so, upon the appearance of persons whose virtues are so elevated that they "admit of no comparison," the state literally withdraws from them, removing its jurisdiction over them. ${ }^{56}$

The danger posed to the polis by individuals of superior virtue is properly understood once we recognize that the constraints of sovereign rule are not legal in nature. Under normal conditions, all laws are possible and all transgressions are manageable. But, as we have seen, normal conditions are not guaranteed and must be continually maintained. The regularity of political life under sovereignty is not, therefore, a consequence of law but the condition for law, and the order of the state is only as robust as the order of obedience that embraces it. The law merely stands in to obscure the constant possibility that this obedience may at any moment collapse or be redirected and thereby usher in a condition of anomie, which is why auctoritas, not potestas, anchors political life. From this point of view, Aristotle's meaning becomes apparent: the seditiousness of individuals who possess too much virtue is not the transgression of law, but the exposure of law in its frailty, an exposure that appears as the potential of establishing a new law or, more profoundly, the potential of being a law unto oneself: a living law, a god among men.

55) Aristotle, Politics 1284a4-22, trans. Benjamin Jowett, ed. Stephen Everson (Cambridge: Cambridge University Press, 1988), 71-72.

56) Equating the polis to a ship at sea, Aristotle adds that, "mythology tells us that the Argonauts left Heracles behind for a similar reason; the ship Argo would not take him because she feared that he would have been too much for the rest of the crew" (Pol. 1284a23-25), ibid., 72. 
The figure of the god among men (theon en anthrôpois) is ancient and is absolutely implicit in the evolution of western political thought, but its presence is complicated by virtue of its appearing in two contrary manifestations. We are confronted by a political concept that preserves authority, on the one hand, while, on the other, threatens to steal it away. Aristotle's analysis arises directly from this dilemma: how does political authority survive the presence of a person whose virtue is an authority of its own? It is, I believe, precisely the problem of auctoritas that is at issue here. For, although Aristotle's remarks are focused on the conditions necessary to exercise justice, "for justice will not be done to the superior," the concealed subject of the passage is not justice at all but authority, which makes justice possible insofar as it makes legitimate the adjudication between subjects. In other words, if "legislation is necessarily concerned only with those who are equal," as Aristotle claims, this is not the case because the supremely virtuous person exceeds state law by responding to a higher authority and is therefore not subject to the laws of man-as one might find in a Platonic formulation - but because virtuousness reveals equality itself to be a fragile construction of the state, a fiction that serves the purposes of justice by guaranteeing that authority remains continuous and singular.

The balance of forces within the state - that fragile status of equality we find privileged in Aristotle-requires that authority remain singular, because the presupposition at work here, which epitomizes all transcendent political philosophies, is that governance proceeds by way of a fundamental reduction of plurality to singularity, the reduction of many decisions to one decision. But between these two poles, between the many and the one, there is a hiatus, a breach between the inclinations of the people, distributed across any possible number of configurations, and the singular binding decision-a gap between the people and the law, between desires and commandments, between interests and the general good, which must be concealed if the framework of government is to remain intact. The risk of having this gap exposed, of revealing the extent to which the power of sovereignty is dependent on the multitude, is what makes the presence of the god among men destabilizing. By offering an alternative source of authority, the god among men reveals state authority to be non-unique, and in being exposed as non-unique the survival of authority within the polis is not, strictly speaking, necessary.

The classical theorists of sovereignty-Bodin, Hobbes, and Rousseau-have all equated kingship with god, and each employ the word "indivisible" to define the character of sovereignty. So, the appearance of a second authority-to quote Derrida's reflections on the unicity of power (where he too touches upon the notion of a "god among men") — “affects God with divisibility precisely 
there where sovereignty... does not suffer division." 57 It is for this reason that, within the constraints of western political logic, there can be no multiplicity of authority, no community of gods. If one were to conceive of such a community, the entire framework of sovereign political power and the juridical order that follows from it would have to be discarded. Echoing Plato's remarks in the Statesman, Rousseau speaks precisely of this political limit, which is expressed as an ontological limit, when he writes that "[i]f there were a people of gods, it would govern itself democratically. [But] so perfect a government is not suited to men."58 The very beings that we are, or that we suppose ourselves to bewhat Aristotle calls a properly human life, namely, political life-bars us from entertaining the possibility of authority that is not singular, and so we are confronted, then, with the fundamental challenge of whether or not it is possible to conceive of a different form of life so as to conceive a different form of politics.

\footnotetext{
57) Jacques Derrida, Rogues: Two Essays on Reason (Stanford: Stanford University Press, 2005), 75 .

58) Jean-Jacques Rousseau, The Social Contract, bk. 3, chap. 4. In Rogues, Derrida writes, "In the Statesman (Politicus), monarkhia is the best of the six constitutions when it is not only constitutional but bound by written laws; it is the worst and most unbearable when it is anomic, that is, when the sovereign is above the law." The case for democracy is the opposite. "when democracy is subject to constitutional laws, it is the worst regime, that last in which one would want to live; but it is the best when the laws are broken. When the written constitution is not respected, one is better off in a democracy than anywhere else." (76).
} 